Markusovszky Egyetemi Oktatókórház, Szombathely, Gnathológiai és Rekonstrukciós Prothetikai szakrendelés* Markusovszky Egyetemi Oktatókórház, Szombathely, Arc-, Állcsont- és Szájsebészeti Osztály** Klinikai Kémiai és Immunanalitikai Laboratórium, Synlab Hungary Kft., Budapest ${ }^{\star \star \star}$ Markusovszky Egyetemi Oktatókórház, Szombathely, Orthodontiai szakrendelés***

\title{
Craniomandibularis diszfunkció klinikai adatainak elemzése 10 éves gnatológiai tapasztalatok alapján
}

\author{
DR. KISS GÉZA*, DR. PÁCZ MIKLÓS ${ }^{\star \star}$, DR. TOLDY ERZSÉBET ${ }^{\star \star \star}$, DR. KISS PÉTER ${ }^{\star \star \star \star ~}$
}

\begin{abstract}
A craniomandibularis diszfunkció (CMD) olyan rágószervi múködési zavar, amely rendkívül komplex kórkép, és számos oka lehet. Tanulmányunk célja a CMD-re jellemző adatok elemzése annak dinamikájában a 10 éves gyakorlatunk során jelentkező betegeink adatai alapján.

1741 beteg (38 \pm 19 év, nő/férfi: 3,7; 348 eset < 18 éves) klinikai, diagnosztikai és terápiás adatait, kezelésük eredményességét rögzítettük a mindennapi gyakorlatunkban használt algoritmus szerint. Vizsgáltuk az egyes diagnózisok előfordulási gyakoriságát a fájdalom megjelenésének típusait, rizikótényezőit a CMD-vel társuló krónikus megbetegedéseket és a kezelés (gyógyszer, sín-terápia és fizioterápia, valamint ezek kombinációi) eredményességét is elemeztük. Eredmények: A klinikai tünetek nemenként nem mutatnak eltérést, viszont a CMD mindegyik típusa erős női dominanciát mutat (közel 4-szeres) és a legtöbb beteg fiatal (20-40 éves) életkorú. A betegek $80 \%$-a fél éven belül fordul panaszaival orvoshoz. A leggyakoribb tünetek az orofacialis fájdalom, ízületi- és izomérintettség $(79,7 \%$ és $71,7 \%)$ volt. A leggyakoribb kórképek: myalgia (31\%), capsulitis és myalgia (24\%), valamint a kompenzált CMD (21\%). Legjelentősebb rizikófaktorok: a parafunkció $(91 \%)$, a malocclusio (87\%), orthodontiai anomália, kiemelten a mélyharapás (42\%) és fedőharapás (10\%), mozgásszervi társbetegségek és occlusiós eltérések. A parafunkció hátterében gyakran psychés/ psychoszociális érintettség $(8,4 \%)$ is igazolódott, illetve ha ez nem volt, akkor a fájdalom-panasz esélye a felére csökkent $\left(\mathrm{OR}=0,53_{\mathrm{Cl} 95 \%: 0,35-0,91}\right)$. Hypermobilitásban (67\%), kompenzált CMD-ben (43\%) észleltük a legtöbb társbetegséget. Közülük is a gerincbetegségek fordultak elő leggyakrabban. Összességében az alkalmazott terápiák az esetek $80 \%$-ában voltak eredményesek.

Eredményeink rámutatnak a CMD diagnosztika komplexicitására, és ez segítheti a diagnosztikai és a sikeres terápiás eljárások időben történő alkalmazását, ebben a főként fiatal és aktív korosztályt érintő, női dominanciát mutató, életminőséget rontó kórképben.
\end{abstract}

Kulcsszavak: craniomandibularis diszfunkció, fájdalom, társuló betegség, női dominancia.

A rágószerv a szervezet egészén belül anatómiai és élettani funkcionális egység, határozott és elkülöníthető feladattal, múködéssel bír. Részei: fogak, fogazat, temporomandibularis ízület, neuromuscularis rendszer, mimikai- és rágóizmok, nyelv, nyálmirigyek és az állcsontok. Integrált müködési egységet alkot, és ennek egyes részei egymás működését befolyásolják és egymásra hatnak [11]. A rágószerv felépítése és funkciója szerint egy speciális mozgásszervnek számít, nem véletlen, hogy a CMD különböző kórformáiban a vázizomrendszer a leggyakoribb társbetegség. Ezzel öszszefüggésben a tünetei is hasonlóak más mozgásszervi megbetegedésekhez. A károsító behatás okozta elváltozásra a szervezet adaptációval vagy kompenzációval válaszolhat. A kötőszöveti és muscularis struktúrákban a túlterhelés következtében regresszió vagy dekompenzáció jön létre, és ez megjelenik a kórkép dinamikájában is. A kötőszöveti struktúrák progresz- szív adaptációjához, az izmokban kompenzációhoz is vezethet. Ha a terhelés túllépi a kritikus hatást, degresszív reakció kezdődik, ami destruktív csontos elváltozást és/vagy izomfájdalmat jelent. A szöveti reakció szerinti fokozatok:

1. Panaszmentes, terhelésre is tünetmentes, azaz adaptált állapot.

2. Kompenzált állapot: szubjektív panaszmentes, terhelés hatására jelentkeznek a tünetek.

3. Dekompenzált állapot: jellemző tünetek (fájdalommal, mozgáskorlátozottsággal) lépnek fel [17].

Fiatal korban adaptációra képes, később kompenzációs hajlam jellemző rá. „Alkotóelemeinek” pathológiás elváltozása, megváltozott funkciója rágószervi működési zavart (cranio-mandibularis dysfunctio, CMD) okoz(hat), melynek primer vagy secunder oka lehet [3]. 
A rágószervi funkciózavar komplex kórkép, multicausalis betegség, szubjektív és objektív tünetekkel, illetve morfológiai és funkcionális elváltozások egymásba való átalakulásával [15]. Nem csak fájdalom, hanem a rágóizmok és nyaki izmok feszülése vagy állkapocs-mozgászavar, ízületi kattanás vagy crepitatio is jelentkezik. Oki kezelés csak akkor lehetséges, ha a kezelöorvos tudja, mely rágószervi struktúrák sérültek és milyen hatás okozta azokat, azaz sikeres kezelés csak pontos kórisme alapján történhet objektív leletek alapján. Ehhez ismerni kell a társuló egyéb betegségeket, gyógyszeres kezelését és az esetleges korábbi traumákat. Természetesen fel kell mérni a fogpótlás, occlusio állapotát, parafunkciók meglétét, amelyek rágószervi funkciózavar kialakuláshoz vezethetnek. Pszichoszociális faktorok (depresszió, félelem-problémák) szintén etiológiai tényezők lehetnek [13].

A rendkívül színes kórkép korrekt diagnózisának felállításában és a megfelelő terápiás döntés meghozatalában az segíthet, ha a beteg minél előbb gnatológiában jártas fogorvoshoz kerül, akinek ezen megbetegedések kórismézésében nagy jártassága van. Mivel a panaszok összefüggésben állnak más társuló betegségekkel, és a betegek számára nem egyértelmú a tünetek lokalizációja az orofacialis regióban, ezért a CMD-s betegek gyakran háziorvosukhoz vagy más szakorvoshoz is fordulnak. Ezért tűztük ki célul, hogy a CMD-s páciensek adatait 10 éves tapasztalataink alapján összegezzük, és rámutassunk a betegséget kiváltó, fenntartó és prediszponáló tényezőkre, valamint a diagnosztikai és terápiás összefüggések feltárásával a gyakorló orvosok figyelmét felkeltsük a CMD-re. Jelen ismereteink szerint hasonló vizsgálati eredményekről, különösen a hazai szakirodalomban eddig kevés és kisebb esetszámon végzett közlemény jelent meg [10, 19, 24, 28, 30, 31].

\section{Anyag és módszer}

2008. január 1-től 2017. december 31-ig a gnatológiai szakrendelésre beutalt (állkapocs-ízületi megbetegedésre gyanús) betegek adatait rögzítettük, és ezeket retrospektíve elemeztük.

\section{Vizsgált esetek}

A 10 év alatt 1741 páciens adatait gyűjtöttük össze, életkoruk hisztogramját, szélsőértékeit és átlagéletkorukat az 1. kép szemlélteti.

Az összes eset $80 \%-a(N=1393)$ felnőtt volt, míg $a<18$ éves korosztály $(\mathrm{N}=348)$ kisebb hányadot tett ki. Mindkét korcsoportban a nemek aránya hasonló volt, erősen női dominanciát (nő/férfi arány: $<18$ éves: 3,8 , felnőtt: 3,6 ) igazolva. A férfiak és a nők átlagéletkora között nem volt lényeges különbség ( $37 \pm 19$ vs. $38 \pm 19$ év). Összességében a legtöbb beteg a 20-40 éves korcsoportba tartozott.
A betegek $56 \%$-a $(\mathrm{N}=977)$ fogszakorvosnál jelent meg, míg mások $(\mathrm{N}=764)$ háziorvoshoz vagy más szakorvoshoz fordultak először panaszaikkal. Megjegyzendő, hogy az első alkalommal is a fogorvosnál jelentkezők a fiatalabbak ( $34 \pm 18$ vs. $42 \pm 20$ év) és dominánsan a nők voltak ( $58 \%$ vs. $42 \%$; $p=0,002$ ), összehasonlítva azokkal, akik a háziorvost vagy más szakorvost kerestek fel panaszaikkal.

\section{A rögzített adatok}

Az összegyűjtött adatok a mindennapi gyakorlatban alkalmazott vizsgálati protokoll szerint (kórelőzmény, klinikai vizsgálat, occlusiós diagnosztika, funkció-analízis és képalkotó eljárások eredményei, a megállapított diagnózisok, kezelések) kerültek feldolgozásra. A beutalt CMD-s páciensek kórlapon rögzített részletes adatait visszakereshető módon, számítógépen rögzítettük.

$A z$ életkoron és a nemen kívül külön feljegyeztük a fog(szak)orvosi és a háziorvosi, valamint egyéb szakorvosi beutalóval küldött betegeket.

A klinikai adatok mind az 1741 esetben rögzítésre kerültek. Az első megjelenéskor a panaszok óta eltelt idő is feljegyzésre került. A rögzített tünetek és panaszok a következők szerint szerepeltek: orofaciális fájdalom lokalizációja és jellege, állkapocsmozgás-zavarok (deviatio, deflexio, korlátozott szájnyitás, deflexio és korlátozott szájnyitás, hypermobilitás, hypermobilitás és deviatio), ízületi érintettség, ízületi hangjelenség, statikus és dinamikus fogérintkezési zavarok, izomérintettség, parafunkciók, testtartási eltérések, a CMD-t befolyásoló társuló betegségek, a klinikai vizsgálattal megállapítható orthodontiai anomáliák (mély-, fedő-, kereszt-, nyitott és élharapás; progénia), fogszabályozási beavatkozások, egyéb malocclusio, hiperbalansz érintkezések, tinnitus [2], pszichoszociális érintettség és a gnatológiai diagnózis.

„Pszichoszociális érintettség” predisponáló és/vagy fenntartó tényezőt a páciens anamnézise, magával ho-

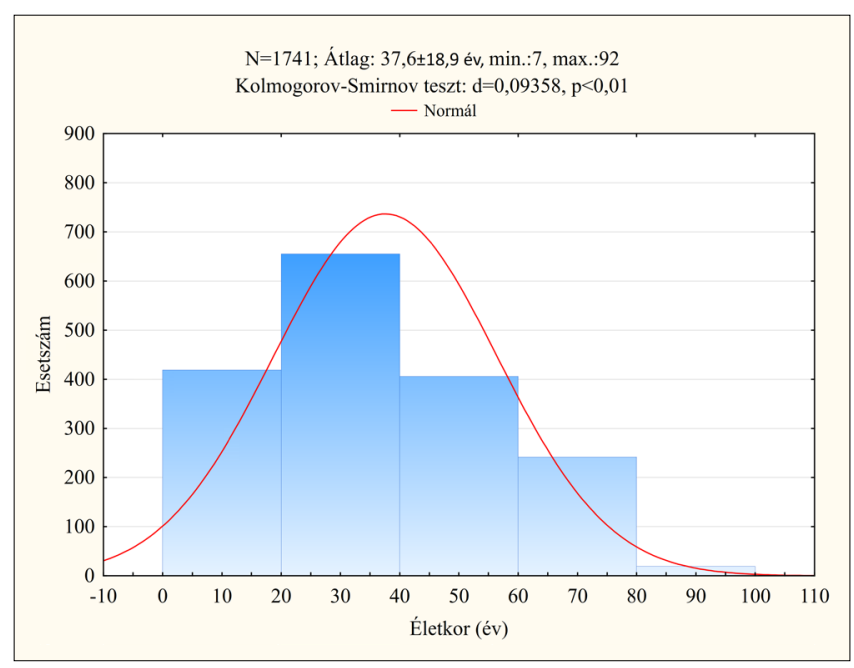

1. kép: A tanulmányban elemzett esetek életkorának hisztogramja 
zott korábbi (főleg neuro-pszichiátriai) leletei, az észlelt személyiség típusa és pszichoszomatikus betegségei, stresszfaktorok és szociális tényezők, valamint viselkedésének, reakcióinak megfigyelése alapján állapítottuk meg, és jegyeztük fel (a pszichiátriai zavarokat nem soroltuk ide). A kezelés sikerességét az öszszehasonlító klinikai (és bizonyos esetekben müszeres) vizsgálat, izomtapintat, aktív mozgások ellenőrzése és nem utolsósorban a páciens értékelése: szubjektív panaszainak csökkenése vagy megszűnése alapján ítéltük meg. „Foghiány vagy fogpótlás jelenléte” együttesen került statisztikai feldolgozásra, mert a foghiányos vagy fogpótlással bíró állapot jelentős predisponáló tényező a CMD kialakulásának folyamatában. A rágósíkban történt lényeges változás vagy változtatás az occlusiós zavar fő okozója lehet. Megfigyelésünk szerint a craniomandibularis diszfunkciós betegek korrekt prothetikai ellátása csak ritkán valósult meg anyagunkban gnatológiai szemlélettel. Saját elemzéseink során mi külön jelöltük az orthodonciai anomáliákat és az ettől független occluiós zavarokat.

Klinikai funkciós vizsgálatot és occlusiós analízist minden betegnél végeztünk. Ennek ismeretében képalkotó (OP vagy más röntgen, $C T$ és $M R$ ) vizsgálat a betegek 3/4-énél $(N=1299)$ történt, elsődlegesen a strukturális elváltozások kimutatására, ill. differenciáldiagnosztikai céllal. Ízületi felszín elváltozásai esetén, osteoarthritis és osteoarthrosis gyanújakor, artrogén laesioknál, sebészi beavatkozás előtt minden esetben CT- és MRI-vizsgálatot végeztünk. Majd az anamnézis, klinikai és képalkotó vizsgálatok ismeretében 579 beteg esetében további digitális múszeres funkcionális (ArcusDigma-3D) vizsgálat is történt [16, 17].

A funkcionális terápiák $(\mathrm{N}=1319)$ módozatai közül a csak gyógyszert ( $\mathrm{N}=78)$, a csak fizioterápiát $(\mathrm{N}=534)$, és occlusiós sín terápiát $(\mathrm{N}=297)$, valamint ezek kombinációit: a gyógyszer + fizioterápia $(\mathrm{N}=79)$, gyógyszer + sín $(N=67)$, fizioterápia + sín $(N=74)$ és a gyógyszer + fizioterápia + sín $(\mathrm{N}=74)$ terápiát mint tünetmentesítő és stabilizáló kezeléseket alkalmaztuk. Definitív terápiát 587 esetben (93 korai érintkezések becsiszolása, 237 fogpótlás, 248 fogszabályozás, 9 sebészi beavatkozás) indikáltunk.

A kezelések eredményességét 1216 betegnél volt alkalmunk vizsgálni.

A páciensek szubjektív megítélése szerint: panaszaik megszűntek, panaszaik csökkentek, átmenetileg javultak. A kiindulási állapothoz viszonyítva klinikai vizsgálatot végeztünk, és vizsgáltuk az aktív állkapocsmozgások jellemzőit is.

Az előbbiek alapján panaszmentessé vált 493, javult 468, átmenetileg javult 44, változatlan 211 és nem jelent meg 514 páciens.

A definitív terápiák a gnatológiai szakvélemény alapján sok esetben más szakrendelésen vagy a beutaló fogorvosnál történtek, vagy visszarendelésünk ellenére nem jelentkeztek a betegek. A klinikai adatok minden esetben rendelkezésre álltak, az elvégzett vizsgá- latok, az alkalmazott terápia elemszáma eltérő, ezért az esetszámokat az eredmények közlésekor mindenkor feltüntettük.

\section{Adatok feldolgozása, statisztikai módszerek}

A nem normál eloszlást mutató (Kolmogorov-Smirnovteszt: $p<0,05$ pl. életkor, panaszok megjelenésétől eltelt idő), illetve a kisebb elemszámú változóinkat medián és interquartilis (Q25-Q75) tartományban tüntettük fel. A gnatológiai diagnózisok alapján 1699 beteg adatait vettük figyelembe. A klinikai elemzésekből a 42 primer állkapocs ízületi megbetegedésben (pl.: ostheoartritis, rheumatoidarthritis, köszvény) szenvedőket kizártuk, mert kezelésük nem gnathológiai feladat elsődlegesen. Az egyes klinikai jelek gyakoriságát \%-ban adtuk meg, a csoportok közötti különbségeket Kruskall-Wallis ANOVAval, illetve a dichotóm jellemzők gyakoriságának öszszevetését Khi2 teszttel, a folytonos változók esetében Mann-Whitney-U teszttel elemeztük. Az orofaciális fájdalomnak a tényét (esélyét) a klinikai adatokkal összefüggésben binaris logisztikus regresszióval is vizsgáltuk. Az esély hányadosokat $(O R) \pm 95 \%$-os konfidenciaintervallummal definiáltuk. A szignifikánsnak bizonyult független változókat egy modellen belül egymásra kontrollálva is vizsgáltuk.

A biostatisztikai kiértékeléseket Statistica for Windows (Vers.12, Microsoft, USA) és SPSS (Vers.25, Microsoft, USA) program használatával elemeztük.

\section{Eredmények}

A diagnózis felállitásához vezető klinikai adatok és egyéb elvégzett vizsgálatok elemzése: a 2. kép jól szemlélteti, hogy a nők szignifikánsan $(p<0,01)$ korábban fordulnak orvoshoz panaszaikkal, míg a $<18$ éves korosztályban nincs eltérés a fiúk és lányok között. Összességében, a korcsoporttól függetlenül a betegek $80 \%$-a

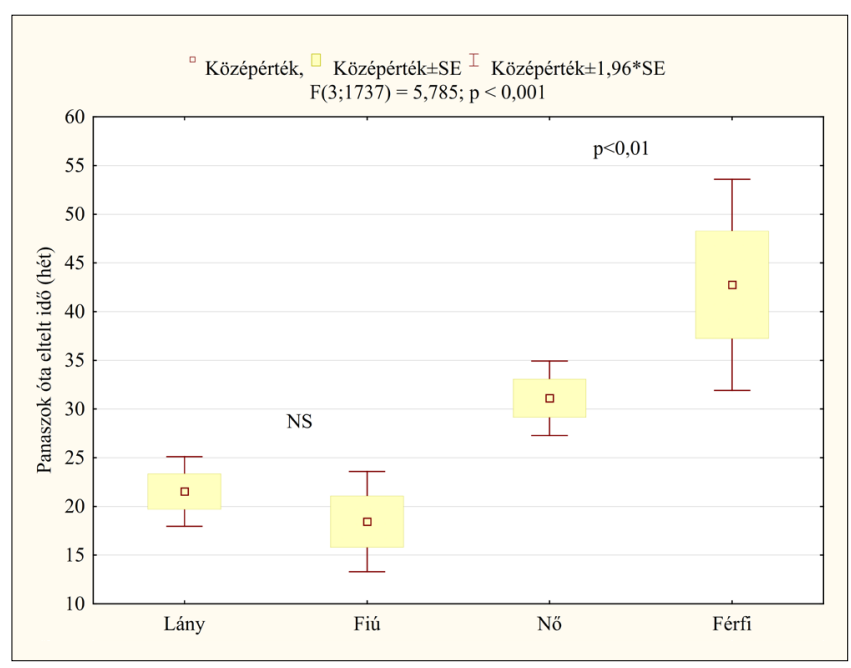

2. kép: A panaszok megjelenésétől az orvoshoz fordulásig eltelt idő 
fél éven belül jelentkezett, ennek közel fele (38\%) 1 hónapon belül és másik fele (42\%) 1-6 hónap között határozta el a szakorvoshoz fordulást.

\section{Tünetek, társuló rendellenességek}

A CMD-ben tapasztalt klinikai tünetek és a társuló további rendellenességek előfordulását az (1. táblázat) összegzi. Megállapítható, hogy a vizsgált 14 tényezőből a leggyakrabban észlelt jelenség a növekvő gyakoriság (92-77\%) sorrendjében: a parafunkció, a statikus és dinamikus fogérintkezési zavar, valamint az orofaciális fájdalom.

1. táblázat

A klinikai tünetek és vizsgálati adatok CMD-ben

\begin{tabular}{|l|r|c|}
\hline Klinikai jelek & $N$ & $\begin{array}{c}\text { Gyakoriság } \\
(100 \%: \mathrm{N}=1699)\end{array}$ \\
\hline Orofaciális fájdalom & 1311 & $77,2 \%$ \\
Állkapocsmozgás-zavar & 1115 & $65,6 \%$ \\
Ízületi hangjelenség*: & 796 & $46,9 \%$ \\
Krepitáció & 120 & $15,0 \%$ \\
Kattanás & 633 & $80,0 \%$ \\
Krepitáció + kattanás & 43 & $5,0 \%$ \\
\hline Statikus fogérintkezési zavar & 1481 & $87,2 \%$ \\
Dinamikus fogérintkezési zavar & 1472 & $86,6 \%$ \\
Izomérintettség ${ }^{\star *}$ & 1219 & $71,7 \%$ \\
Parafunkció*** & 1561 & $91,9 \%$ \\
Ízületi érintettség & 1345 & $79,7 \%$ \\
Testtartási eltérés & 774 & $45,4 \%$ \\
Társuló betegség & 751 & $44,2 \%$ \\
Foghiány/fogpótlás & 933 & $54,9 \%$ \\
Ortodonciai anomália & 885 & $51,2 \%$ \\
Tinnitus & 90 & $5,3 \%$ \\
Pszichoszociális érintettség & 142 & $8,4 \%$ \\
\hline
\end{tabular}

* Az izületi hangjelenségek közül a kattanás volt leggyakrabban észlelhető.

** feszülés, tapintási érzékenység vagy fájdalom, tónusfokozódás, spontán vagy rágáskor jelentkező fájdalom

*** Bruxizmus, fogszorítás, ajak- és bucca harapás, rossz szokások, extrém rágógumizás, fogkopások, nyálkahártyatünetek csaknem minden betegnél jelentkeztek.

Az orofaciális fájdalom típusos megjelenésének részleteit a 3. kép szemlélteti. Az izoláltan jelentkező izomfájdalom kisugárzó és nem kisugárzó formája $(N=597)$ - ha ízületi fájdalommal is társul - szignifikánsan $(p<$ 0,001 ) dominált az összes ízületi és egyéb típusú fájdalmakhoz képest.

Az orofaciális fájdalmat az egyéb klinikai adatokkal összefüggésben, bináris logisztikus regresszióval vizsgáltuk. (2. táblázat)

Megállapítható, hogy a fájdalom és az életkor között szignifikáns pozitív az összefüggés, bár a fájdalom esélye csak 2,7-4,1\%-kal jelentkezik gyakrabban az életkor előrehaladtával. A nemek esetében a nők fájdalom panasza közel 2-szer nagyobb eséllyel következik be, mint a férfiaké. A fájdalom tényének esélye kicsi (3-6\%), de szignifikánsan nő a panaszok óta eltelt idővel. $\mathrm{Ha}$ az izomérintettség fennáll, a fájdalom megléte közel 27-szer nagyobb, mint az izomérintettség nélküli esetekben. Az ízületi érintettség és a foghiány/fogpótlás 2,5-2,7-szeresére növeli a betegség fájdalmas voltát.

A pszichoszociális érintettség szignifikánsan, közel 1,8-szeresére növeli a betegek fájdalom panaszát. Orthodonciai anomália fennállta esetén a fájdalom közel kétszer nagyobb eséllyel bekövetkezik. Ugyanakkor a fogérintkezési zavar, a testtartás, tinnitus, parafunkció és a fájdalom között nem igazolódott szignifikáns öszszefüggés (NS).

A jónak ítélt kezelések hatására az orofaciális fájdalomról a betegek, csak 0,093-as eséllyel számolnak be.

Ha a nemet, életkort és a panaszok óta eltelt időt mint független prediktorokat egy regressziós modellbe elemeztük, akkor is a 3 változó jósló értéke ugyan csökkent, de mindhárom szignifikáns $(p<0,001)$ maradt (a részletes adatokat nem közöljük). Amennyiben az izom- és ízületi érintettséget, foghiány/fogpótlást, orthodontiai anomáliákat és a pszichoszociális érintettséget egy regressziós modellben elemeztük, akkor a jósló értékük az orofaciális fájdalomra többnyire csökkent, de szignifikáns maradt, míg a pszichoszociális érintettség szignifikáns hatását elveszítette. (3. táblázat)

Az állkapocs-mozgászavarok részletes elemzésekor (4. kép) a korlátozott szájnyitás, a hypermobilitás és a deviációval társult hypermobilitás az esetek mindegyike közel egyharmadában fordul elő, együtt több mint 3/4-ét teszik ki.

Orthodontiai anomáliákon belül domináns a mélyharapás ( $N=371)$ és fedőharapás ( $N=92)$, együtt $52 \%$, míg a keresztharapás és egyéb malocclusiós esetek száma együttesen $(\mathrm{N}=271) 30 \%$. (5. kép)

A CMD-n belül előforduló kórformák gyakoriságát a 6. kép szemlélteti. Betegeink körében a myalgia, és ennek capsulitissel való társulása, valamint a kompenzált CMD bizonyult a leggyakoribb gnatológiai betegségnek. Müszeres funkciós vizsgálatokat a 7. kép összesíti,

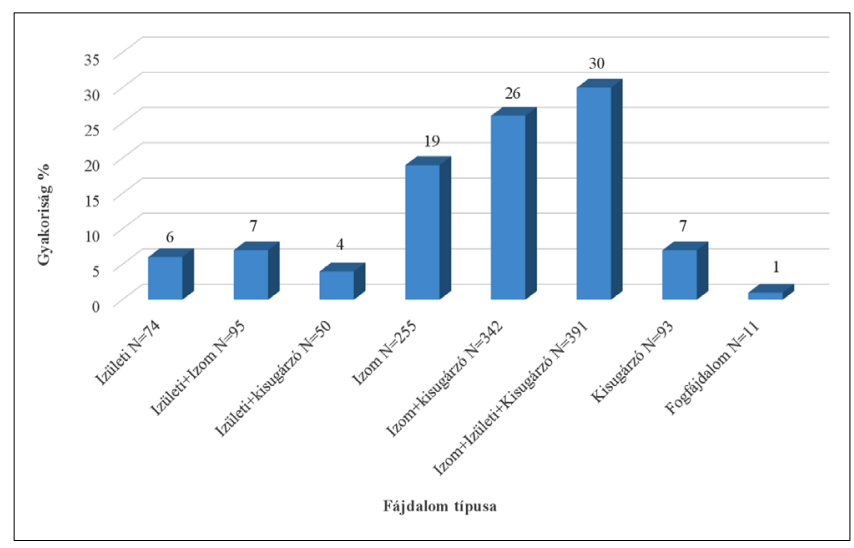

3. kép: Az orofacialis fájdalmak típusos megjelenései $(\mathrm{N}=1311)$ 
Összefüggés az orofaciális fájdalom-panasz és az egyéb klinikai adatok között

\begin{tabular}{|c|c|c|c|c|c|c|}
\hline \multirow{3}{*}{$\begin{array}{l}\text { Független változók } \\
\text { A } 13 \text { változó külön-külön modellbe téve }\end{array}$} & \multicolumn{6}{|c|}{$\begin{array}{c}\text { Függő változó: } \\
\text { Orofaciális fájdalom } \\
\text { (bináris kód: } 0=\text { nincs, } 1 \text { = van) }\end{array}$} \\
\hline & \multirow{2}{*}{$B$} & \multirow{2}{*}{$S E$} & \multirow{2}{*}{$P$} & \multirow{2}{*}{ OR } & \multicolumn{2}{|c|}{$95 \% \mathrm{Cl}$} \\
\hline & & & & & Alsó & Felsö \\
\hline 1. Életkor (év) & 0,033 & 0,004 & $<0,001$ & 1,034 & 1,027 & 1,041 \\
\hline 2. Nem (nő) & 0,674 & 0,130 & $<0,001$ & 1,962 & 1,519 & 2,533 \\
\hline 3. Panaszok óta eltelt idő (hét) & 0,004 & 0,001 & $<0,001$ & 1,004 & 1,003 & 1,006 \\
\hline 4. Fogérintkezési zavar (van) & - & - & NS. & - & - & - \\
\hline 5. Testtartási rendellenesség (van) & - & - & NS. & - & - & - \\
\hline 6. Tinitus (van) & - & - & NS. & - & - & - \\
\hline 7. Parafunkció (van) & - & - & NS. & - & - & - \\
\hline 8. Izomérintettség (van) & 3,284 & 0,151 & $<0,001$ & 26,734 & 19,812 & 35,901 \\
\hline 9. Izületi érintettség (van) & 0,938 & 0,178 & $<0,001$ & 2,555 & 1,804 & 3,619 \\
\hline 10. Foghiány/Fogpótlás (van) & 1,012 & 0,120 & $<0,001$ & 2,750 & 2,170 & 3,480 \\
\hline 11. Pszichoszociális érintettség (van) & 0,575 & 0,244 & 0,018 & 1,780 & 1,120 & 2,872 \\
\hline 12. Orthodonciai anomália (van) & 0,664 & 0,123 & $<0,001$ & 1,943 & 1,526 & 2,474 \\
\hline 13. Kezelés hatása (jó) & $-2,376$ & 0,173 & $<0,001$ & 0,093 & 0,066 & 0,13 \\
\hline
\end{tabular}

Összefüggés az orofaciális fájdalom-panasz és az öt klinikai adat között

\begin{tabular}{|c|c|c|c|c|c|c|}
\hline \multirow{2}{*}{ Egy modellben vizsgált 5 független változó } & \multirow{2}{*}{$B$} & \multirow{2}{*}{$S E$} & \multirow{2}{*}{$p$} & \multirow{2}{*}{ OR } & \multicolumn{2}{|c|}{$95 \% \mathrm{Cl}$} \\
\hline & & & & & Lower & Upper \\
\hline Izomérintettség & 3,276 & 0,157 & 0,000 & 26,472 & 19,463 & 36,006 \\
\hline Izületi érintettség & 0,699 & 0,219 & 0,001 & 2,012 & 1,310 & 3,091 \\
\hline Foghiány/Fogpótlás & $-0,754$ & 0,160 & 0,000 & 0,471 & 0,344 & 0,644 \\
\hline Pszichoszociális érintettség & $-0,126$ & 0,305 & 0,679 & 0,881 & 0,485 & 1,602 \\
\hline Orthodontiai_Anomalia & 0,580 & 0,165 & 0,000 & 1,787 & 1,294 & 2,468 \\
\hline Constant & $-0,532$ & 0,160 & 0,001 & 0,587 & & \\
\hline
\end{tabular}

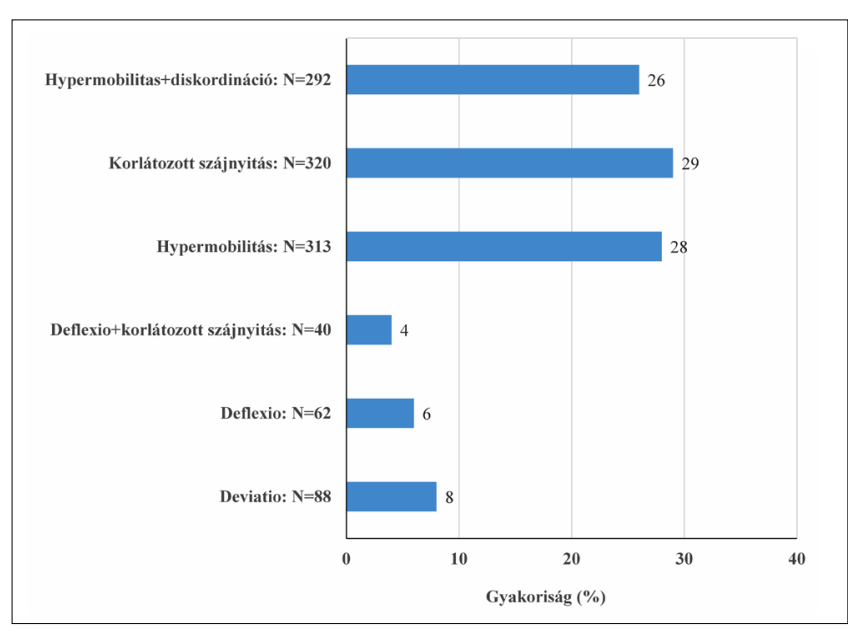

4. kép: A különböző állkapocs-mozgászavarok megoszlása $(\mathrm{N}=1115)$

amelyből kitünik, hogy a discus-dislocatio és a hypermobilitás azok a diagnózisok, amelyek felállításához szignifikánsan több $(\mathrm{p}<0,001)$ múszeres vizsgálatot végeztünk, mint a többi CMD kórformában.

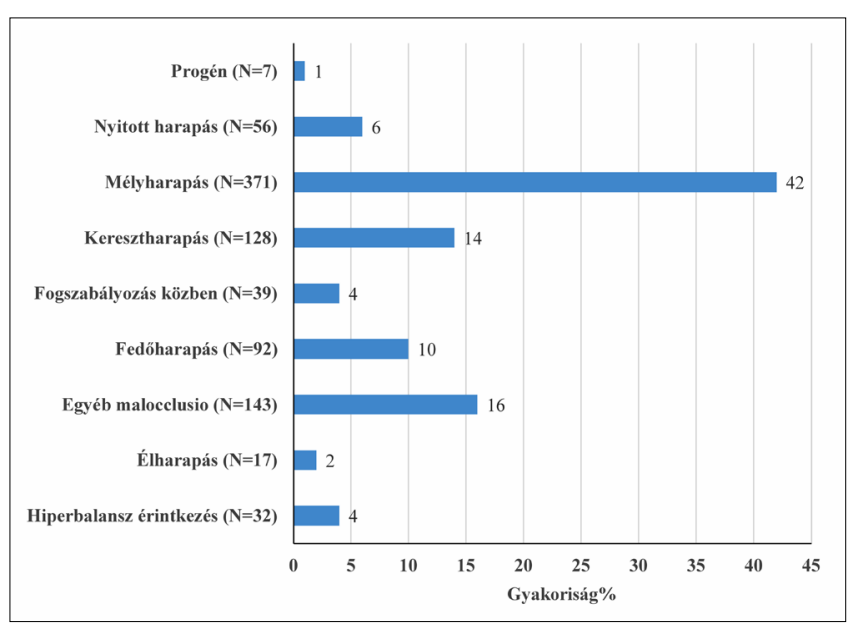

5. kép: CMD-t provokáló orthodontiai tényezők megoszlása beteganyagunkban $(\mathrm{N}=885)$

A gnatológiai diagnózisok ismeretében elemeztük a panaszok óta eltelt időt. (8. kép) A myalgia, capsulitis és e kettő együttes diagnózisával rendelkező betegek szignifikánsan $(p<0,001)$ korábban jelentkeznek pana- 
szaikkal, mint a hypermobilitással, discus-dislocatio-val és kompenzált CMD-ben szenvedő esetek.

Azon társuló kórképek gyakoriságát, amelyek befolyásolhatják a cranio-mandibularis rendszer működését, a 9. kép szemlélteti a gnatológiai diagnózisok vonatkozásában.

A hypermobilitás $(67 \%)$ és a kompenzált CMD (43\%) legtöbbször laza ízületekkel, míg a többi kórkép főként gerincbetegséggel társult, 44-71\%-os gyakorisággal.

A kezelések eredményességét (10. kép) összességében megfelelőnek tarthattuk a betegek $82 \%$-ában $(\mathrm{N}=973)$. A hét gnatológiai diagnózis csoporton belül, 96-98\%-os eredményességet tapasztaltunk a myalgia, capsultis és e kettő együttes előfordulásakor, valamint a discus-dislocatio esetében is, viszont a CCMD betegek panaszai 13\%-ban nem enyhültek. A kompenzált CMD esetekben, csak kevesebb mint felénél értünk el eredményes kezelést. Hypermobilitásban szenvedő betegek 22\%-a szintén rosszul reagált a kezelés hatására. Utóbbi a kórkép veleszületett/alkati jellegével magyarázható. A kompenzált CMD tulajdonképpen instabil állapot, a károsító behatást egy ideig a rágószervrendszer adaptációval tolerálja.

\section{Megbeszélés}

A CMD multicausalis megbetegedés, melynek ún. major és minor tünetei vannak, ill. kialakulásában és manifesztálódásában szerepet játszanak iniciáló faktorok, prediszponáló és fenntartó tényezők, valamint befolyásolja a szervezet adaptációs készsége is. A kórkép idült túlterhelés során alakul ki, amikor a kezdeti, károsító behatásokra először kompenzációval reagál a craniomandibularis rendszer. Ha az iniciáló tényező túllépi a kritikus határt, degresszív reakció indul el különböző tünetekkel és panaszokkal, melyek közül a fájdalom sok esetben jellemzője a megbetegedésnek, és hosszan tartó fennállása esetén egyéb tünetek oki tényezőjeként szerepel.

A nagyszámú betegadat elemzésével nyert tapasztalataink az esetek többségében a szakirodalmi adatokhoz hasonlóak, és igazolják a betegség rendkívül változatos klinikai megjelenését [1, 14, 19, 23, 24]. A CMD előfordulását közel négyszeres női dominanciával igazoltuk mind a 18 év alatti $(3,8)$, mind a felnőttek $(3,6)$ esetében. Ez az adatunk, az irodalmi adatoknak éppen úgy megfelel, mint az, hogy betegeink életkorukat tekintve fiatalok, s ez megerősíti Madléna és mtsai [23] megállapítását, mely szerint a 35-44 éves korosztály érintett ebben a betegségben leginkább, tehát a CMD nem öregkori megbetegedés. Mindez magyarázható részben Leitgeb [9] azon megfigyelésével is, mely szerint nőknél a pubertáskortól emelkedik, és a menopauza után már ritkább a betegség megjelenése, ezért a panaszok manifesztté válásában hormonhatást is feltételeznek.

A panaszok megjelenése óta az orvoshoz fordulás idejét elemezve megállapítottuk, a betegek kb. három- negyede fél éven belül jelentkezik orvosnál, míg a gyermekek előbb kerülnek vizsgálatra, közel 1/3-uk már 1 hónapon belül. Imhoff [14] adatai hosszabb időtényezőt említenek (közel 1 év).

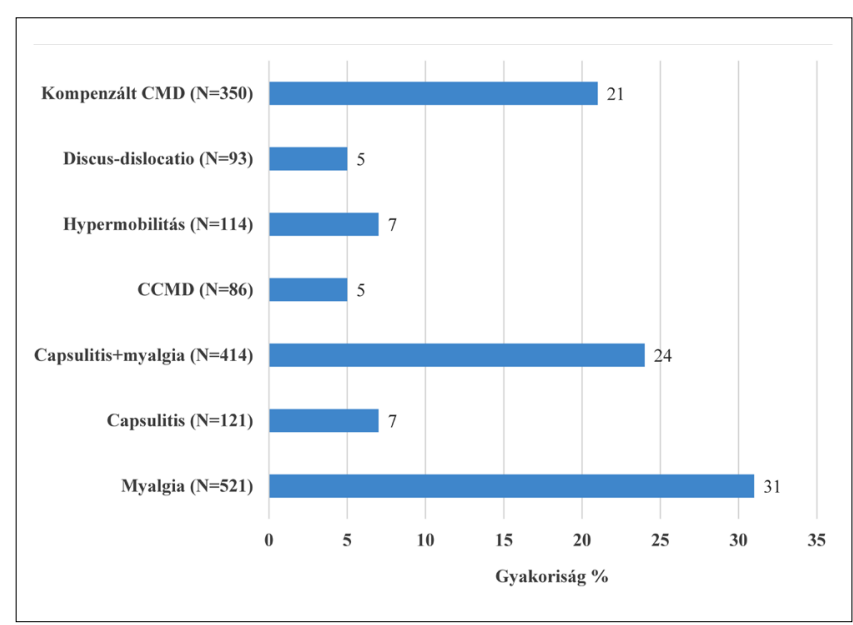

6. kép: A gnatológiai kórképek gyakorisága $(\mathrm{N}=1699)$

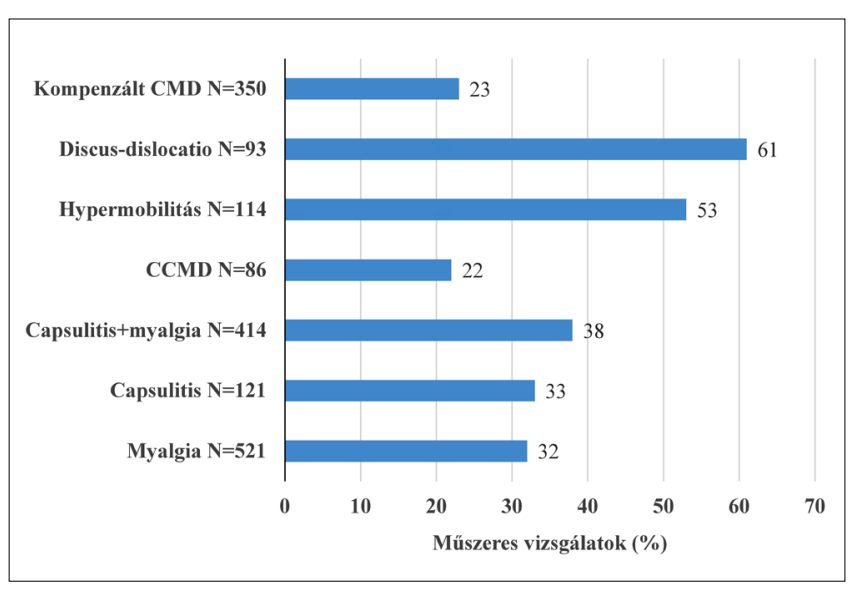

7. kép: Múszeres funkcionális vizsgálatok $(\mathrm{N}=579)$

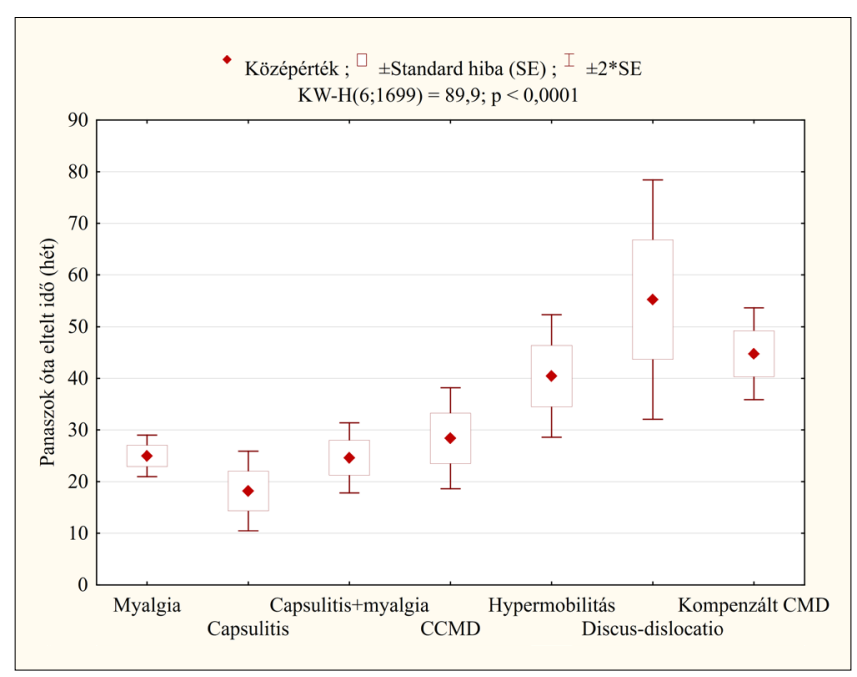

8. kép: Panaszok óta eltelt idő az egyes gnatológiai kórképek esetében 


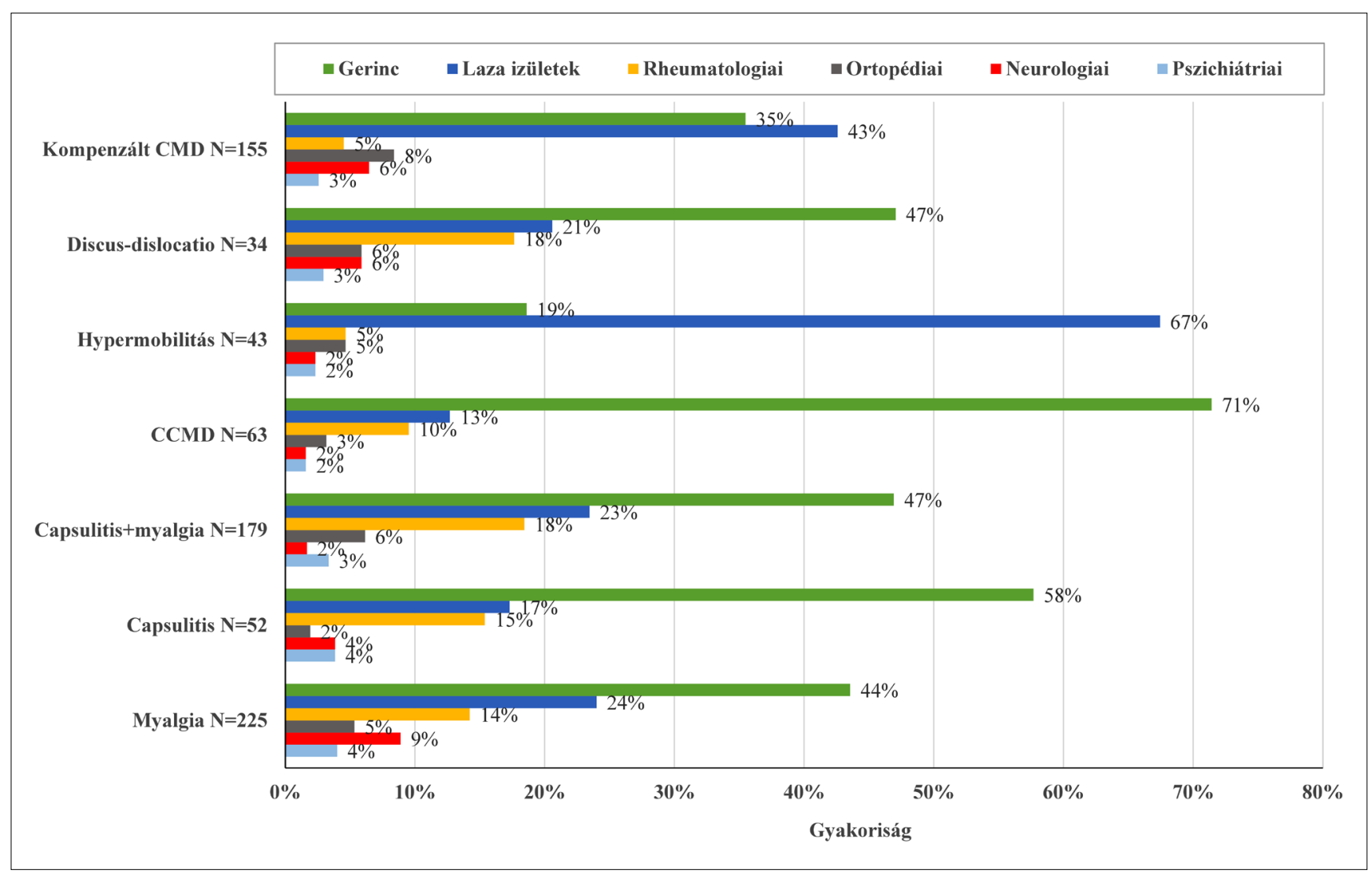

9. kép: Az egyes gnatológiai kórképekhez társuló betegségek aránya $(\mathrm{N}=751)$

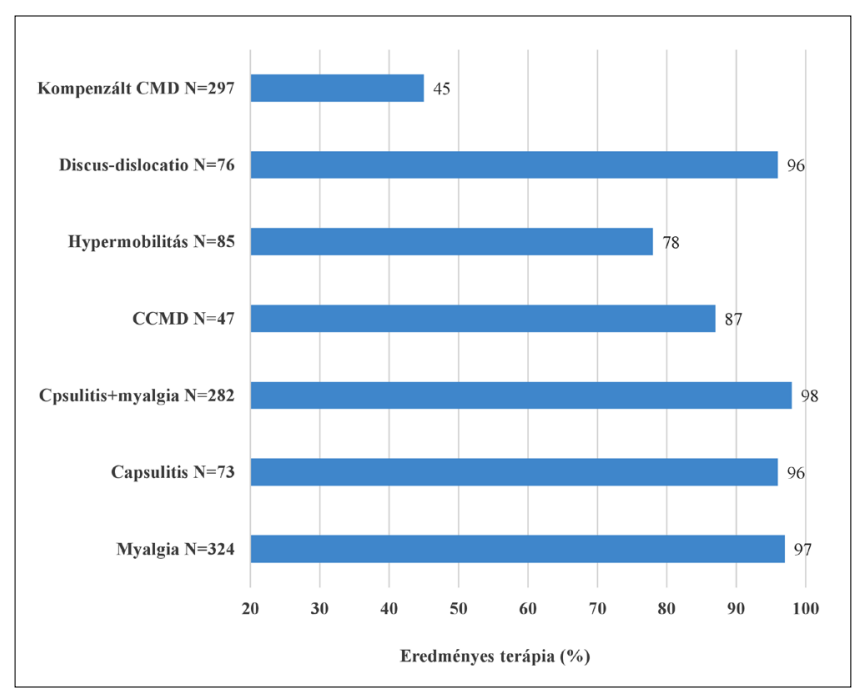

10. kép: A terápia eredményessége az egyes gnatológiai diagnózisok vonatkozásában $(\mathrm{N}=1216)$

Azt is megállapítottuk, hogy a nők szignifikánsan $(p=$ 0,025 ) korábban fordulnak orvoshoz panaszaikkal, mint a férfiak, míg a fiúk-lányok között nem volt ebben különbség. Viszont, különbség van az egyes kórformák esetében is: megváltozott funkcióval járó, ám fájdalommal nem társuló betegségben (discus dislocatio, kompenzált CMD és hypermobilitás) a leghosszabb (40-
55 hét) a várakozási idő az orvoshoz fordulásig. Ez azt feltételezi, hogy elsődlegesen a fájdalom (pl. capsulitis, myalgia) viszi hamarabb orvoshoz a beteget, és ez szignifikánsan kimutatható (18-25 hét).

A betegeink nagyobb százaléka (56\%) fogszakorvosnál jelentkezett először, míg a többiek háziorvoshoz vagy más szakorvoshoz (fül-orr-gégész, ideggyógyász stb.) fordultak panaszaikkal. A fiatalabbak közül többen inkább fogorvosnál jelentkeztek, míg az idősebbek többségükben a háziorvost vagy más szakorvost keresték fel panaszaikkal. Mindez azzal magyarázható, hogy a panaszok lokalizációja orientálja a páciensek orvosválasztását. Ez is arra hívja fel a figyelmet, hogy gnatológiai ismereteket és összefüggéseket az alapellátás és a határterületek szakorvosai felé is közvetíteni kell.

A fájdalom domináns panasz, önállóan vagy társtünetként, számadataink szerint a páciensek több mint háromnegyedénél jelentkezik. Az izomfájdalom ( $m$. pterygoid. lat., $\mathrm{m}$. temporalis és $\mathrm{m}$. masseter pars superfic.) a legjellemzőbb tünetek közé tartozik. Más szerzők leírásában is a páciensek többségénél az izomtapintat fájdalmas volt $[6,8,9,15,24,29]$. A fájdalom hasonlóan domináns panasz volt betegeink körében is, önállóan vagy társtünetként, a betegek háromnegyedénél.

Jelentős számban (54\%) tapasztaltunk állkapocs-mozgászavart. Utóbbi a laza ízületekből adódik, és gyakran a többi ízületben is észlelhető. E jelenség kötőszöveti 
gyengeségre vezethető vissza. A 40 mm-nél kisebb szájnyitás korlátozottnak minősül [12].

A parafunkció (bruxizmus, fogszorítás, ajak- és buccaharapás, rossz szokások, extrém rágógumizás) az emberek zömére jellemző rizikótényező, és az életkorral emelkedik [14]. Parafunkció gyakorisága mutatkozott meg betegeinknél is, több mint 90\%-ban [13]. Más szerzők ennek előfordulását nem találták olyan gyakran, [21, 22, 24] mint azt a mi adataink igazolták (77\%). Egy tübingeni tanulmányban parafunkció az esetek $52 \%$-ában volt megfigyelhető [24]. Ember és mtsai [10] összefüggést találtak a diszfunkció foka, a maradó fogak számának csökkenése, az occlusios zavar, a parafunkció és a bruxizmus között. Carlsson és mtsai [5] a bruxizmust és egyéb oralis parafunkciókat szintén veszélyeztető faktorként írták le a temporomandibularis ízületi panaszok kialakulásában.

Társuló betegségeket elemző adataink a vázrendszeri, ill. izom-mozgásszervi betegségek elsődleges jelenlétét mutatják. Összefüggés van a CMD és a pszichés stressz között [2, 24]. Utóbbi sok esetben parafunkciót okoz, mint pl. bruxizmus. Több szerző szerint a pszichoszociális/pszichés tényezők manapság jelentős szerepet játszanak a CMD etiológiájában [27]. A pszichoszociális vonatkozások különösen a középkorú nők esetében lehetnek figyelemre méltók [23]. Vágó szerint [30, 31] a CMD kialakulásában a parafunkciós és pszichés tényezők a szignifikáns etiológiai faktorok, amelyeket a hibás occlusio és az általános egészségi állapot döntően befolyásol. Van Selms és mtsai [26] szintén a pszichológiai faktorok jelentős szerepét hangsúlyozzák. Saját vizsgálatainkban a pszichoszociális tényezők érvényesülése a fájdalom panaszának esélyét szignifikánsan megnövelte.

Az orthodontiai anomáliák egyúttal occlusiós zavarokhoz is sorolhatók, mint ahogy több szerző így kategorizálja. Liu és mtsai [20] a CMD és orthodontia összefüggésében megállapítja, hogy lányoknál a pubertáskorban a tünetek gyakrabban jelentkeznek. Rizikótényezők: egyoldali keresztharapás és malocclusio. A temporomandibularis ízületi kóros működésre utaló tünetek közel 41\%-ában fordul elő mélyharapás vagy nyitott harapás, leggyakrabban a 35-44 éveseknél, férfiaknál magasabb arányban [23]. A diszfunkció kóroki tényezői között az egyik leggyakoribbak közé tartozik [30, 31].

A teljes populációban szignifikáns összefüggést lehetett kimutatni a mélyharapás és az ízületi fájdalom, valamint a mélyharapás és az ízületi hangjelenség elöfordulása között $(p<0,05)[23]$.

A kezelés eredményességét értékelve megállapítható, hogy betegeinknél $80 \%$-ban sikerült panaszmentességet vagy jelentős javulást elérni. Akiknél sikertelen volt a kezelés, föként hypermobilitásban vagy CCMD-ben szenvedtek. Ezen kórképek közül a hypermobilításról ismert tény, hogy alkati adottság, és ezért konzervatív terápiával kevésbé javítható. Viszont a CCMD kezelésének kevésbé sikeres eredménye a vázrendszer érintettségével magyarázható [3]. Wagner tanulmánya [32] szerint az arthrogén elváltozásoknál megfelelő kezeléssel a páciensek kb. $90 \%$-a panaszmentessé tehető. Krok [18] anyagában megállapítja, hogy az izomfájdalom a leggyakoribb CMD-tünet, és kombinált kezelések hatására $88,9 \%$-ban sikeres a szubjektív tünetek kezelése.

\section{Konklúziók}

- A CMD aktív (munkaképes) életkorban a legjellemzőbb, női dominanciát mutat.

- Panaszok között az ízületi fájdalommal társult izomfájdalom szignifikánsan a leggyakrabban előforduló tünet $(p<0,001)$

- CMD-ben szenvedők gyakran fordulnak háziorvosukhoz vagy más határterületi szakorvoshoz (pl. fül-orrgégész, ideggyógyász stb.), ezért gnatológiai ismereteket és összefüggéseket kell közvetíteni e szakterületek orvosaihoz.

- Úgy tűnik, hogy jelentős rizikótényező az orthodontiai anomália, ezért - különösen felnőtteknél - a fogszabályozó kezelés előtt funkciódiagnosztikus vizsgálat indokolt. A valószínűség egyértelmű bizonyításához kontrollcsoport-vizsgálat szükséges.

- A fogszabályozást érintő adatunk rámutat az iskolafogászati szúrővizsgálatok jelentőségére, valamint felnőtteknél az első fogorvosi vizsgálatkor az orthodontiai eltérésekre is kiemelten figyelemmel kell lenni, bár ezek megfelelő értékelése orthodontiaban és/vagy gnatológiában jártasságot kíván.

- Fontos, hogy minden fogszabályozási kezelés előtt a vizsgálati státusban rögzíteni kell a funkcióra vonatkozó adatokat.

- Kompenzált stádiumban a rágószerv instabil állapotú; fogérintkezési zavarra és parafunkcióra minden esetben figyelemmel kell lenni.

- A már kialakult CMD tünetek esetén nagy számban találtuk mélyharapás előfordulását, ez arra utal, hogy a mélyharapás játszhat jelentősebb szerepet a temporomandibularis ízületi panaszok kiváltásában.

- Nagyobb figyelmet kíván a kompenzált CMD felismerése (adatainkban 21\%-kal szerepel), mert ezekben az esetekben fontos a profilaxis a folyamat progreszsziójának - megfelelő instrukcióval és motivációval való megelőzése.

- Múszeres funkcióvizsgálat leginkább discus dislocatio és hypermobilitás eseteiben indokolt, ill. e kórképekben várható ennek eltérő eredménye.

- Szignifikáns összefüggést lehetett kimutatni a mélyharapás és az ízületi fájdalom, valamint a mélyharapás és az ízületi hangjelenség előfordulása között.

- A hypermobilitás önmagában és a deviációval való együttes előfordulása (55\%) csaknem kétszer gyakoribb állkapocsmozgás-zavar, mint a korlátozott szájnyitás (28\%).

- A funkcióterápiás eljárások (mint rossz szokásokról való leszoktatás, gyógyszeres kezelés, fizioterápia, 
gyógytorna, occlusiós sín vagy ezek kombinációja) jó hatásfokkal alkalmazhatók; a fájdalom megszűnésének esélye 10,7-szeres.

- A tinnitus (az esetek 5,3\%-ában fordult elő) és a fájdalom között nem igazolódott szignifikáns összefüggés, azaz a tinnitusos betegeknek általában nincs fájdalmuk.

\section{Irodalom}

1. Bagis B, Ayaz EA, Turgut S, Durkan R, Özcan M: Gender Difference in Prevalence of Signs and Symptoms of Temporomandibular Joint Disorders: A Retrospective Study on 243 Consecutive Patients. Int J Med Sci 2012; 9 (7): 539-544. https://doi.org/10.7150/ijms.4474

2. BernhARDt O: CMD und Tinnitus: Evidenz and Management. Ernst-Moritz-Arndt Universität, Greifswald.

3. Bumann A, Lotzmann U: Funktionsdiagnostik und Therapieprinzipien. Georg Thime Verlag, Stuttagart, 2000. 275-277.

4. Carlsson GF: Epidemiology and teratment need for temporomandibular disorders. J Orofac Pain 1999; 13: 232-237.

5. Carlsson GF, Egermark I, Magnusson T: Predictors of signs and symptomes of temporomandibular disorders: A 20-yers followup study from childhood to adulthood. Acta Odontol 2002; 60: 180-185. https://doi.org/10.1080/000163502753740214

6. COOPER BC, COOPER DL: Multidisciplinary approach to the differential diagnosis of facial, head and neck pain. J Prosthet Dent 1991; 66: 72-78. https://doi.org/10.1016/0022-3913(91)90356-2

7. DAPPRiCH J (ed.): Funktionstherapie in der zahnärztlichen Praxis. Quintessenz, Berlin, 2004.

8. Darlow LA, Pesco J, Greenberg MS: The relationship of posture to myofascial pain dysfunction syndroma.

J Amer Dent Assoc 1987; 114: 73-75. https://doi.org/10.14219/jada.archive.1987.0053

9. DwORKIN SF, MASSOTH DL: Temporomandibular disorders and chronic pain: disease or illness? J Prosthet Dent 1994; 72: 29-38. https://doi.org/10.1016/0022-3913(94)90213-5

10. EmBer E, VÁGó P, BAGI I, et al: Temporomandibularis diszfunkció epidemiológiai vizsgálatának újabb vonatkozásai magyarországi populációban.

Fogorvosi Szemle 1987; 80: 139-144.

11. FÁBIÁN T, Götz GY, KAÁN M, et al: A fogpótlástan alapjai. Semmelweis Kiadó, Budapest, 1997. 103-104.

12. Ferrario VF, Sforza C, Lovecchio N, Mian F: Quantification of translational and gliding components in human temporomandibular joint during mouth opening. Arch Oral Biol 2005; 50: 507-515. https://doi.org/10.1016/j.archoralbio.2004.10.002

13. Hermann P, Szentpétery A. (ed.): Gnatológia. Semmelweis Kiadó, Budapest, 2018. 258-277.
14. ImHoff B, Hellmann D: TMD - a question of age? $J$ of Craniomandibular Function 2017; (2): 1-14.

15. KaRES H: Schmärzhafte Beschwerden der Kaumusculatur und der Kiefergelenk. Complement Integre Med 2008; 05: 30-34. https://doi.org/10.1016/.j.kim.2008.03.012

16. KIss G, KIss $P$, PÁcz M: A stomatognath rendszer ultrahangosszámítógépes modullal kiegészített funkcionális vizsgálata. Fogorvosi Szemle 2005; 98 (4): 145-152.

17. Kıss G, PÁcz M, Kiss P: Rágószervi funkciózavarok diagnosztikája. Craniomandibularis rendszer dysfunkciója (CMD). Fogorvosi Szemle 2011; 104 (3): 93-102.

18. K Квок: Therapiemöglichkeiten der myogenen Dysfunktion. Diplomarbeit, Med. Univ. Graz, 2014.

19. LEITGEB E: Häufigkeitsvorkommen stomatognather Dysfunktionen - eine retrospektive epidemiologische Studie anhand von 630 Patientenfällen. Diplomarbeit, Universitätsklinik Graz, 2015.

20. Liu F, Steinkeler A: Epidemiology, Diagnosis, and Treatment of Temporomandibular Disorders. Dent Clin N Am 2013; 57: 465-479. https://doi.org/10.1016/j.cden.2013.04.006

21. LoBbezZo F, LAVIGNE GJ: Do bruxism and temporomandibular disorders have a cause- an effect relationship? J Orofac Pain 1997; 11: 15-23.

22. Lotzmann U: Orale Parafunktionen und Abrasionen der Zähne. Georg Thieme Verlag, Stuttgart, 2012. 122-135.

23. Madléna M, Fejérdy $P$, KaÁn M, Hermann $P$ : Temporomandibularis ízületi és vertikális orthodonciai rendellenességek előfordulási gyakorisága, valamint azok összefüggései nagyszámú populáció szűrővizsgálata alapján. Fogorvosi Szemle 2015; 108 (1): 25-31.

24. MarX-Janson (geb. Kraus) L: Craniomandibuläre Dysfunktion. Querschnittsstudie der Prävalenz im Einzugsbereich Tübingen (eine retrospektive Datenerhebung). Disszertáció, Universitätsklinik Tübingen, 2011.

25. Parsché E: Funktionslehre I., Biomechanik. Scriptum Med. Univ. Graz, 2006.

26. van Selms MK, Lobbezzo F, Wicks DJ, Hamburger HL, Naeije M: Craniomandibular pain, oral parafunctions and psychological stress in a longitudinal case study. $J$ Oral Rehabil 2004; 31: 738-745. https://doi.org/10.1111/j.1365-2842.2004.01313.x

27. Strub JR, Kern M, Türp JC, Witkowski S, Heydecke G, Wolfart S: Curriculum Prothetik, Band I. 4. Auflage, Quintessenz, Berlin, 2011.

28. Szentpétery A, Fazekas A, Rudas K. A temporomandibularis fájdalom-diszfunkciós szindróma epidemiológiai vizsgálata fogorvostan-hallgatókon. Fogorvosi Szemle 1986; 79: 193-197.

29. TRAVELL JG: Temporomandibular Joint pain referred from muscles of head and neck. J Prosth Dent 1996; 10: 745-763. https://doi.org/10.1016/0022-3913(60)90257-2

30. VÁGó P: Az állkapocsízületi diszfunkció kóroktanának vizsgálata I. Keresztmetszeti vizsgálat. Fogorvosi Szemle 1989a; 82: 203-208.

31. VÁGó P: Az állkapocsízületi diszfunkció kóroktanának vizsgálata II. Statisztikai módszer. Fogorvosi Szemle 1989b; 82: 237-241.

32. D WAGNER: Therapiemöglichkeiten der arthrogenen Dysfunktion. Diplomarbeit, Med. Univ. Graz, 2014. 


\author{
KIss G, PÁcz M, Toldy E, KISS P
}

\title{
Analysis of clinical data for craniomandibular dysfunction based on 10 years of gnathological experience
}

Introduction, objectives: Craniomandibular dysfunction (CMD) is a masticatory dysfunction that can be extremely complex with several causes. The purpose of this study is to analyse based on our patient's data in our 10-year experience the details specific to CMD. Material and method: Clinical, diagnostic and therapeutic data of 1741 patients (38 \pm 19 years, 348 cases $<18$ years, female/male: 3.7 ) were recorded according to the algorithm used in our daily practice. We also examined the incidence of each diagnosis, the types of pain onset, the risk factors for chronic diseases associated with $\mathrm{CMD}$, and the effectiveness of treatment (drug, splint therapy and physiotherapy, as well as the combinations of these). Results: Clinical symptoms do not differ according to gender, but all types of CMD show strong female dominance (nearly 4-fold) and most patients are young (20-40 years). Overall, $80 \%$ of patients seek medical care within six months. The most common symptoms were parafunction (91.9\%), dental contact disorder (86.9\%) orofacial pain $(77.2 \%)$, joint and muscle involvement $(79.7 \%$ and $71.7 \%)$. The most common diseases were myalgia (31\%), capsulitis + myalgia (24\%), and compensated CMD (21\%). The most important risk factors are orthodontic abnormalities, especially deep overbite $(42 \%)$ and top bite (10\%), skeletal comorbidities and occlusal differences. Complained parafunction often associated with psychological/psychosocial involvement (8.4\%) and, if not, the chances of a pain sensation were halved (Odds ratio: $0.53 \mathrm{Cl}$ 95\%: 0.35-0.91). Hypermobility (67\%) and compensated CMD (43\%), associated with several common comorbidities in which the most prevalent was the vertebral disorders. Overall, the therapies used were successful in $80 \%$ of the cases. Conclusions: Our findings highlight the complexity of CMD diagnostics and may help timely application of diagnostic and successful therapies in this predominantly juvenile, female-dominated disorder, which compromising the quality of life.

Keywords: craniomandibular dysfunctions, pain, associated disease, female dominance 